\title{
First record of Eurasian Water-milfoil, Myriophyllum spicatum, for the Saint John River, New Brunswick
}

\author{
Meghann Bruce ${ }^{1,}$, , Tommi Linnansaari ${ }^{1}$, and R. Allen Curry ${ }^{1}$ \\ ${ }^{1}$ Canadian Rivers Institute, Biology, Forestry and Environmental Management, University of New Brunswick, Fredericton, \\ New Brunswick E3B 5A3 Canada \\ ${ }^{*}$ Corresponding author: meghann.bruce@unb.ca
}

Bruce, M., T. Linnansaari, and R.A. Curry. 2018. First record of Eurasian Water-milfoil, Myriophyllum spicatum, for the Saint John River, New Brunswick. Canadian Field-Naturalist 132(3): 231-237. https://doi.org/10.22621/cfn.v132i3.1943

\begin{abstract}
Eurasian Water-milfoil (Myriophyllum spicatum L.) is regarded by conservation practitioners as one of the most challenging invasive aquatic plants to manage. Owing to its broad tolerance to environmental conditions, vegetative propagation, and rapid establishment and growth, $M$. spicatum introductions have the potential to drastically alter macrophyte species assemblages via a loss of native species and their respective ecosystem functions. Following the discovery of a single specimen of $M$. spicatum in the Saint John River, near Fredericton, New Brunswick (Canada) we further investigated the localized distribution of this nonindigenous species. Thirteen areas were identified as potential M. spicatum habitat and were surveyed by wading or snorkeling. Specimens of M. spicatum were collected and morphological identifications were verified through genetic analyses (ITS2; $r b c \mathrm{La}$ ). The results of our investigation confirm the presence of $M$. spicatum at six different locations within the Saint John River. Here we discuss the implications of this discovery in the context of the contiguous aquatic habitats along a large river system.
\end{abstract}

Key words: Eurasian Water-milfoil; Myriophyllum spicatum; aquatic invasive; Saint John River

\section{Introduction}

Approximately $15 \%$ of non-indigenous plant species become invasive causing irreversible disruptions to ecosystem functions (Westbrooks 1998). In aquatic environments, not only do invasive plants alter floristic assemblages via loss of native species (Aiken et al. 1979; Boylen et al. 1999) and their respective ecosystem functions (Duffy and Baltz 1998; Thomaz and da Cunha 2010) and compromise habitat for many other species, but they also alter environmental flows, nutrient cycling, and can directly influence water quality (Zedler and Kercher 2004; Kovalenko and Dibble 2010; Villamagna and Murphy 2010). Additionally, invasive aquatic plants often grow to high densities and are detrimental to the economic, recreational, and aesthetic qualities of waterways (Newroth 1985; Eiswerth et al. 2000). Mitigation of the negative impacts of aquatic introductions requires active control measures and is costly (Pimental et al. 2004).

One of the five most noxious aquatic plant invaders of aquatic ecosystems is Eurasian Water-milfoil (Myriophyllum spicatum L.; Cronk and Fennessy 2001). Native to Eurasia and northern Africa (Sennikov 2016), M. spicatum is now present on every continent except Antarctica (Cook 1985). While the impacts of the introduction of $M$. spicatum vary in magnitude among different aquatic environments and in different regions (Smith and Barko 1990), it is generally acknowledged among scientists and conservation practitioners that this species frequently establishes dense, monospecific beds that outcompete local flora and reduce the diversity and abundance of native species (Grace and Wetzel 1978; Madsen et al. 1991; Boylen et al. 1999). In some in- stances, this species has outcompeted native flora in as little as 2-3 years (Aiken et al. 1979; Newroth 1985; Boylen et al. 1999). Considered the most widely managed invasive aquatic plant in the United States (Bartodziej and Ludlow 1998), M. spicatum is on several regional invasive species watch lists and is listed as one of the ten most unwanted species in Maine, USA (Hill and Williams 2007), and New Brunswick, Canada (New Brunswick Alliance of Lake Associations website: http: //www.nbala.ca/new-page-1).

The vector and timing of introduction of $M$. spicatum to North America is not completely understood. While Couch and Nelson (1985) suggest M. spicatum was introduced to North America in the 1940s, Reed (1977) reviewed historical herbarium specimens and provided evidence that the earliest verified records of $M$. spicatum from North America are dated back to at least 1881 but acknowledged that the introduction was possibly as early as 1848. It is not uncommon for non-indigenous species to exhibit an initial lag in their growth before they become invasive, and many non-indigenous aquatic plant introductions go unnoticed until they are established as truly invasive. Thus, it is highly probable that M. spicatum was present in North America as early as 1848 and Couch and Nelson's (1985) report regarding introduction in the 1940s more accurately reflects the timing at which this species was first observed as invasive.

In an assessment of historical records for the distribution of M. spicatum in North America, Reed (1977) also observed a disjunct distribution with populations in eastern North America, southeastern North America, and an isolated region in California. He attributed this dis- 
junction to independent introductions that were most likely a consequence of the release of aquarium plants, as various species of Myriophyllum were commonly cultured and distributed for the aquarium trade at this time (Reed 1977). While the release of aquarium plants may be the original source of introduction events across North America, introduction to new waters is now primarily attributed to fragments introduced by boats and their associated trailers (Johnson et al. 2001; Rothlisberger et al. 2010).

Successful eradication of recently established invasive species populations is highly dependent on rapid detection and prompt management actions (Willby 2007). Two factors may hinder the rapid detection of M. spicatum: difficulty in detection because it is primarily beneath the water's surface and difficulty in identification versus similar native congeners (especially the sister species Siberian Water-milfoil, M. sibiricum Komarov) because the key morphological features vary with phenotypic plasticity (Strand and Weisner 2001) and/or hybridization (Sturtevant et al. 2009).

While conducting macrophyte surveys for 171 sites along the Saint John River (SJR) as a part of a larger aquatic ecosystem study, the Mactaquac Aquatic Ecosystem Study (http://canadianriversinstitute.com/rese arch/mactaquac-aquatic-ecosystem-study/), we discovered a single inconspicuous specimen of $M$. spicatum. Prior to our discovery of this species in the SJR, Hinds (2000) reported that this species had been collected from a small pond in Fundy National Park (Hinds 2000: 667). The introduction of $M$. spicatum to the SJR poses a threat to the submerged aquatic flora within the river and associated waterways. To assess the local distribution of this non-indigenous species, we used an active survey approach that involved snorkelling surveys of potential habitat and molecular approaches (DNA analyses) to verify our taxonomic identifications.

\section{Methods}

To identify potential $M$. spicatum habitat for this survey we looked for areas in the Fredericton region of the SJR (where the first specimen was initially collected) that were consistent with habitat conditions reported for this species (Aiken et al. 1979). Our survey emphasized sheltered cove environments or other low flow areas with soft substrate, as well as areas with frequent boat traffic (Figure 1). Where necessary, snorkelling surveys were conducted to ensure we could observe the submerged flora.

Apical portions of plants morphologically identified in the field as M. spicatum were collected and preserved as herbarium vouchers stored at the Connell Memorial Herbarium (UNB IH) at the University of New Brunswick (Table 1). Leaf tissue sub-samples were dehydrated in silica for subsequent genetic analyses (Fazekas et al. 2012). Dehydrated tissue was sent to the Canadian Centre for DNA Barcoding (CCDB) for DNA extraction, PCR amplification, and sequencing according to $\mathrm{CCDB}$ standardized protocols (Fazekas et al. 2012). To facilitate comparison of our genetic results with taxonomic data available in GenBank (NCBI Resource Coordinators 2016) and the Barcoding of Life Data System (Ratnasingham and Hebert 2007) we selected two standard land plant DNA barcode markers, $r b c$ La and ITS2 (Fazekas et al. 2012).

\section{Results and Discussion}

Analyses of ITS2 and $r b c$ La sequence data was consistent with the morphological-based identification of M. spicatum at six of 13 sites surveyed (Table 1). Four of the six sites where $M$. spicatum is present had only a few scattered plants (Table 1). The remaining two sites where this species was found had patches where it was clearly established as dense macrophyte beds (Figure 2). To assess the potential future impact of this introduction on the native aquatic flora, we reviewed what has been reported for the biology of this invasive species and considered what risks this may present for the aquatic environments along the SJR.

\section{Reproduction}

Myriophyllum spicatum shoots emerge and exhibit rapid growth from an overwintering rhizomatous mass in the early spring and throughout summer. As the growing season progresses, plant growth peaks at the water surface where stems are highly branched forming dense floating canopy (Titus et al. 1975). Vegetative portions of the plants break off throughout the growing season and in the fall when plants typically die back to the propagating rhizome crowns (Aiken et al. 1979).

Fragmented vegetative portions are the primary mode of reproduction and spread for $M$. spicatum within an aquatic ecosystem (Kimbel 1982). In the SJR, downstream spread of this species via vegetative fragmentation is naturally facilitated by peaks in hydrological flows, as well as seasonal ice scouring. The spread of $M$. spicatum between watersheds is largely attributed to vegetative material transported by boat motors and trailers (Johnson et al. 2001; Rothlisberger et al. 2010). In the Fredericton region of the SJR where we have confirmed the presence of $M$. spicatum, further spread by boat motors is a concern as this area is frequently used by recreational boaters. Consequently, this increases the potential of the species to move in larger, discontinuous jumps, enabling the species to spread upstream and to new water bodies.

Like many successful invasive species, $M$. spicatum has multiple modes of reproduction and frequently exhibits sexual reproduction in addition to vegetative fragmentation. Perhaps more concerning than the ability to undergo both asexual and sexual reproduction, is the ability of $M$. spicatum to hybridize with its native sister species $M$. sibiricum to produce plants that exhibit "hybrid vigor" - plants with competitive phenotypes that are superior to both parent species (Moody and Les 2002, 2007; Sturtevant et al. 2009). This hybridization, between an introduced invasive species and a native 


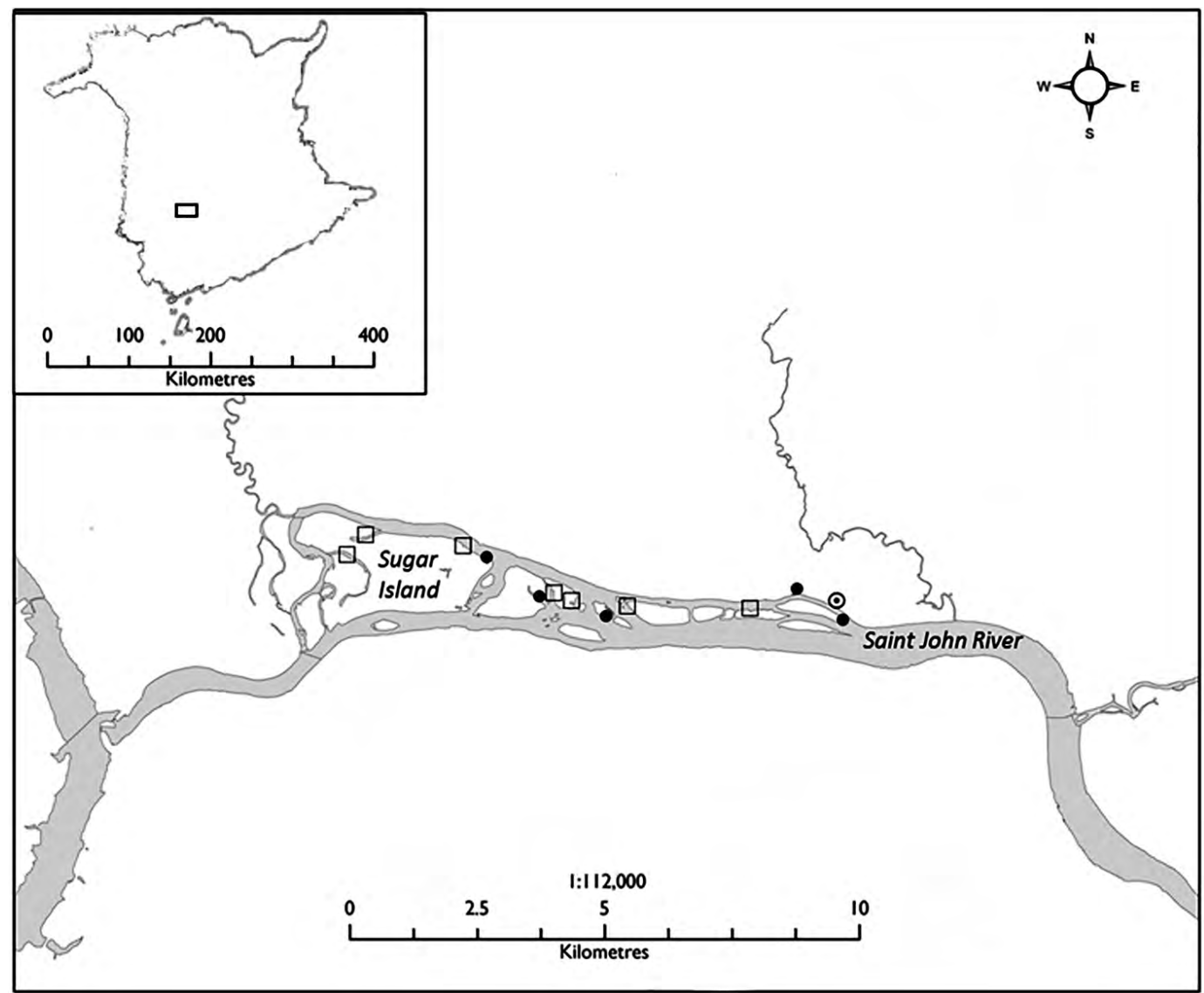

FIGURE 1. Six sites within the Fredericton region of the Saint John River where specimens of Eurasian Water-milfoil (Myriopphyllum spicatum) were collected and identified (denoted by “”). $\odot=$ original site of collection; $\square=$ potential M. spicatum habitat investigated but species was not present.

species, can result in "genetic pollution" introducing new alleles to the population and potentially wiping out locally adapted genotypes (Laikre et al. 2009). In New Brunswick, the native species $M$. sibiricum is classified as potentially vulnerable (S3/S4) and is widespread on the lower SJR system (S. Blaney pers. comm. February 2015). Thus, the ecological risks posed by the potential hybridization of M. spicatum and M. sibiricum are two-fold: hybridization may give rise to populations the exhibit hybrid-vigor and promote further colonization and populations of the native species, M. sibiricum, may be put at risk due to genetic pollution or competition pressure with M. spicatum or M. spicatum $\times$ M. sibiricum hybrids.

\section{Habitat and area for potential colonization}

Most commonly establishing in water with depth ranging 1-3 $\mathrm{m}$, M. spicatum has been reported as deep as $10 \mathrm{~m}$ (Aiken et al. 1979), reaching $7 \mathrm{~m}$ high. Plants thrive in eutrophic lakes with soft organic substrates but persist in a wide range of substrates and environmental conditions (Nichols and Shaw 1986). With regard to water quality, M. spicatum is able to persist in a wide $\mathrm{pH}$ range (5.4-11), tolerate salinity up to $15 \mathrm{ppt}$, and tolerate various industrial pollutants (Aiken et al. 1979; Wang et al. 1996). When growing in shallow areas susceptible to drops in water level that may leave it exposed, M. spicatum assumes a terrestrial form allowing it to gradually become stranded and survive (Aiken et al. 1979). The broad environmental tolerance in this species enables it to colonize various types of lakes, wetlands and salt marshes, or river margins, coves, and inner island channels as observed in our surveys. Downstream of our confirmed M. spicatum population is approximately $130 \mathrm{~km}$ of river with extensive seasonal flood plain and contiguous habitat that has high potential for colonization by this species.

The Grand Lake Meadows (GLM), located approximately $40 \mathrm{~km}$ downstream from the sites of the $M$. spicatum occurrence, is the largest freshwater wetland and floodplain in New Brunswick. It includes the provincial Grand Lake Class II Protected Natural Area (GL PNA). Recent surveys of the flora in the area report 98 rare species that contribute $20 \%$ of the total flora (Papoulias et al. 2006). One of the taxa reported, Budding 


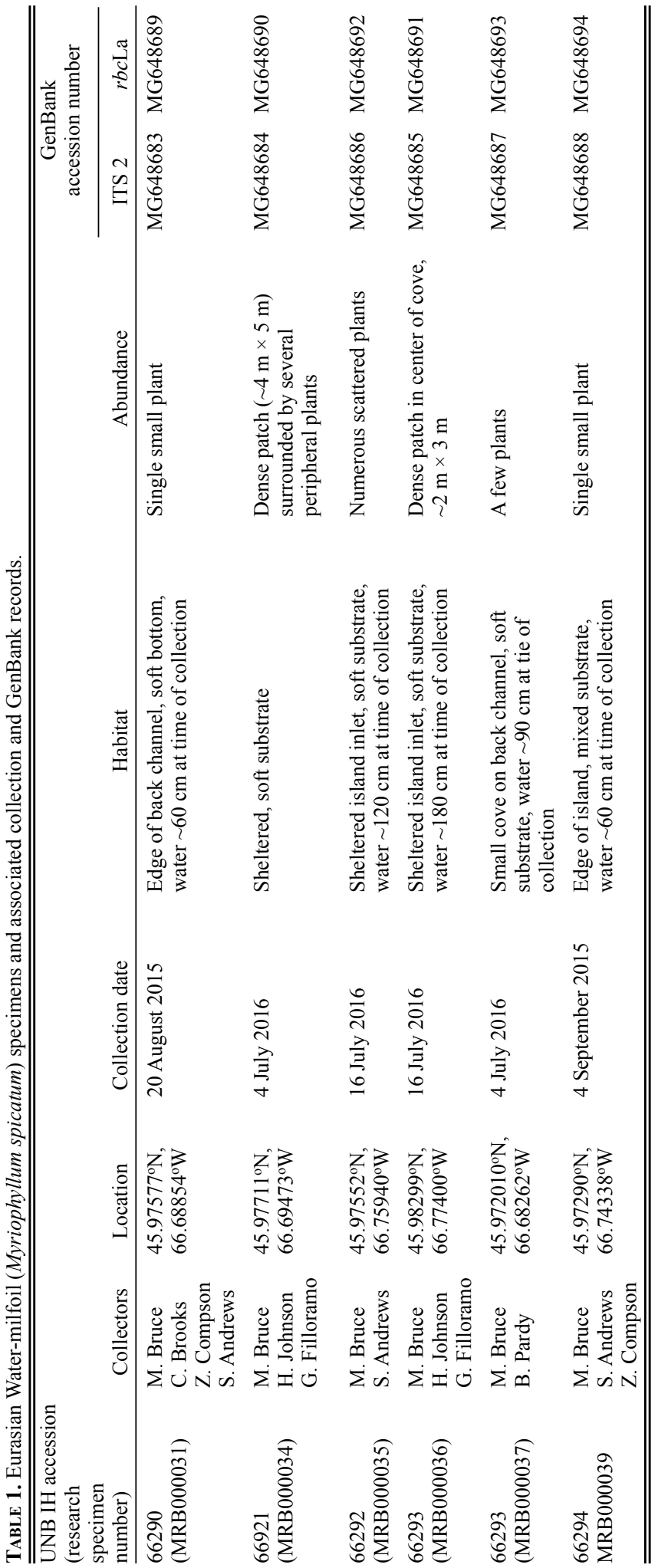



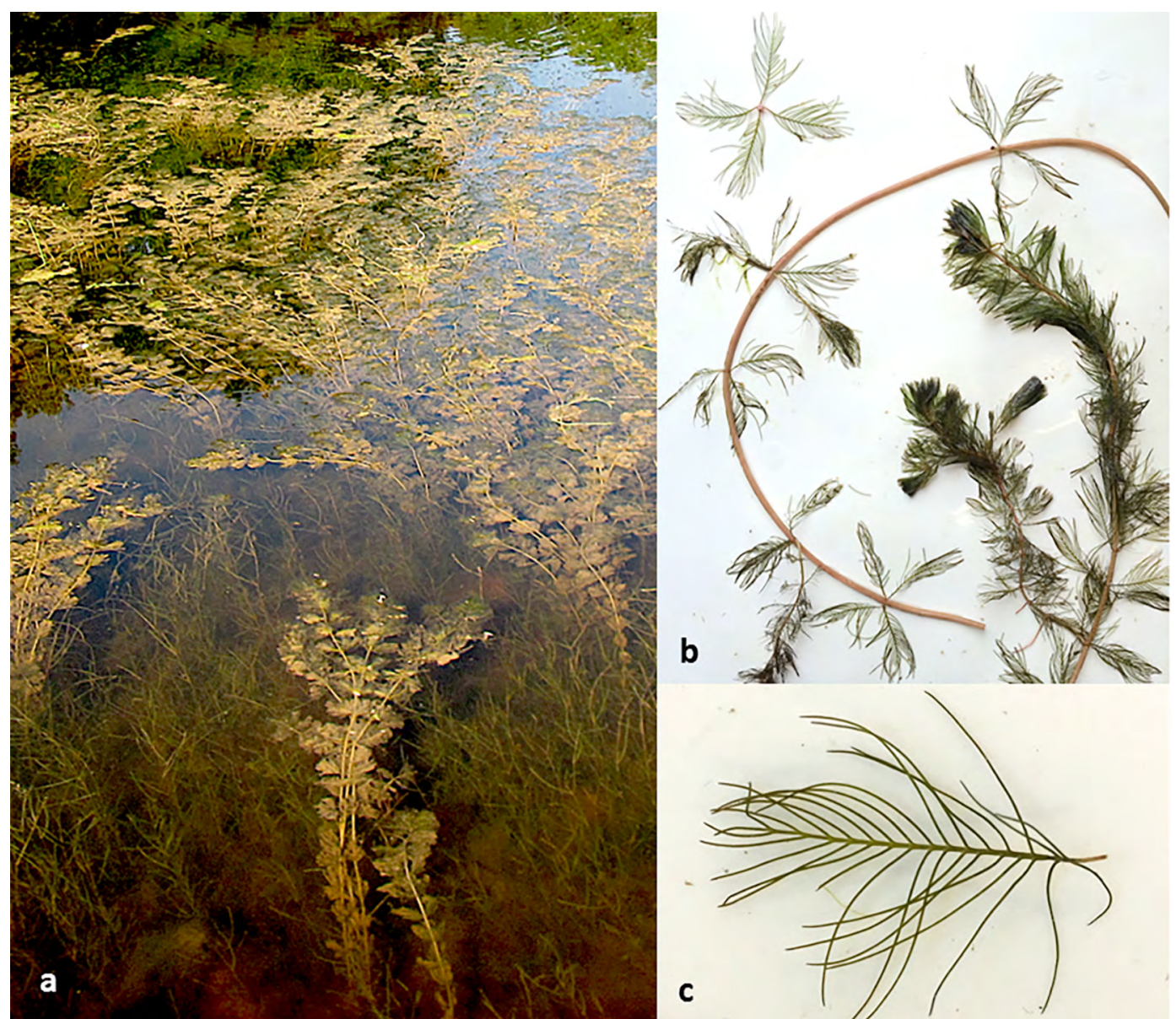

FIGURE 2. Eurasian Water-milfoil (Myriophyllum spicatum). a. Overall habit, plants growing in a dense patch with a high degree of branching, forming a canopy at the water surface. b. Specimen of M. spicatum showing leaves in whorls of four along stem. c. Single pectinate leaf with 15 pairs of pinnae. Photos: M. Bruce.

Pondweed, Potamogeton berchtoldii subsp. gemmiparus (J.W. Robbins) Les \& Tippery, is the only known record of this species for New Brunswick and it is rare on the national level (Papoulias et al. 2006). In the spring, the SJR floodplain spills into the GLM and GL PNA, downstream of our confirmed populations of M. spicatum. The GLM and the GL PNA is thus an area of special concern that should be monitored for a potential M. spicatum invasion.

\section{Options for controlling further spread}

Early detection of M. spicatum and minimizing risk of further spread of early introductions hold the most promise for aquatic ecosystem management (Willby 2007). For individual plants, or small stands of M. spicatum, shading with a black cloth that inhibits photosynthesis can kill the plants (Bailey and Calhoun 2008). This could be an option for the plants that were found in this study, or small isolate populations in other areas. Another option that may be useful (for at least this area of the SJR) is to reduce water flow when air temperatures drop to freezing in early winter. Exposing the crown of the plant to freezing temperatures has shown some success in managing populations of this species in other areas (Bates and Smith 1994; Wagner et al. 2008). Considering that our observed plants were all in shallow areas below the Mactaquac Hydrogeneration Station (MGS) which have been observed to be exposed at times when the MGS retains water (M.B. pers. obs. early August 2015 and 2017), this could be an option for managing the small populations in this area. Where M. spicatum has established as invasive, raking of vegetation helps to temporarily reduce biovolume; however, reproductive fragments render application of this method as high-risk for further spread. Herbicides and the introduction of natural pests have also shown some promise, although the previous studies do not assess potential negative impacts to non-target native species within the aquatic ecosystem (Creed 1998; Cock et al. 2008). 


\section{Conclusions and future investigations}

With knowledge of the presence of this non-indigenous species within the SJR, we intend to quantitatively assess the amount of potential downstream habitats available for colonization by developing spatial models of potential habitat. Spatial models have been used in a number of ecological and biological studies to identify links between the abiotic and biotic environment (e.g., Milhous et al. 1981; Milhous 1999). Such models use environmental variables, such as velocity, substrate composition, temperature, etc., to explain the presence and spatial distribution of biota of interest (e.g., Dunbar et al. 2011). We intend to build a spatial model to (a) identify habitat utilized by $M$. spicatum and (b) apply our model to the SJR to identify areas that may potentially be available for colonization.

Unfortunately, we currently cannot ascertain when or how this species arrived, or the full extent of this species' range in the SJR. Our immediate priority is to extend our survey coverage and to determine if $M$. spicatum is present beyond the range we have observed. Prior to the recreational boating season, we will engage local conservation practitioners and develop an action plan to educate and engage the public as to the presence of M. spicatum in this region in an effort to minimize the further spread of this species and mitigate the negative effects of already established occurrences.

\section{Acknowledgements}

This research was funded by NB Power and Natural Sciences and Engineering Research Council Collaborative Research and Development Grant 462708-13. We would like to thank Cody Brooks, Sam Andrews, Hayden Johnson, Dr. Gina Filloramo, and Dr. Zaccheaus Compson for their assistance conducting field surveys, as well as Maria Kuzmina at the Canadian Center for DNA Barcoding and her input and assistance with the generation of ITS2 and $r b c$ La sequence data. Bronwyn Fleet-Pardy and Antoin O'Sullivan are acknowledged for their help with ArcGIS. We thank Sean Blaney at the Atlantic Canadian Conservation Data Center for communications and clarification regarding Myriophyllum species of interest in the SJR region.

\section{Literature Cited}

Aiken, S.G., P.R. Newroth, and I. While. 1979. The biology of Canadian weeds: 34 Myriophyllum spicatum. Canadian Journal of Plant Science 59: 201-215. https://doi.org/10. 4141/cjps79-028

Bailey, J.E., and J.K. Calhoun. 2008. Comparison of three physical management techniques for controlling variableleaf milfoil in Maine Lakes. Journal of Aquatic Plant Management 46: 163-167.

Bartodziej, W., and J. Ludlow. 1997. Aquatic vegetation monitoring by natural resources agencies in the United States. Lake and Reservoir Management 13: 109-177. https://doi. org/10.1080/07438149709354302

Bates, A.L., and C.S. Smith. 1994. Submersed plant invasions and declines in the southeastern United States. Lake and
Reservoir Management 10: 53-55.https://doi.org/10.1080/ 07438149409354173

Boylen, C.W., L.W. Eichler, and J.D. Madsen. 1999. Loss of native aquatic plant species in a community dominated by Eurasian watermilfoil. Hydrobiologia 415: 207-211. https://doi.org/10.1007/978-94-017-0922-4_29

Cock, M.J.W., P. Häfliger, H.L. Hinz, G. Grosskopf, and M. Seier. 2008. A review of the distribution and recorded natural enemies of Eurasian watermilfoil (Myriophylum spicatum L.) in Eurasia, and the potential for classical biological control in North America. CAB Reviews: Perspectives in Agriculture, Veterinary Science, Nutrition and Natural Resources 3: 1-20. https://doi.org/10.1079/pavsnnr 20083019

Cook, C.D.K. 1985. Worldwide distribution and taxonomy of Myriophyllum species. Pages 1-7 in Proceedings of the First International Symposium on the watermilfoil (Myriophyllum spicatum) and Related Haloragaceae Species. Edited by L.W.J. Anderson. Aquatic Plant Management Society, Vancouver, British Columbia, Canada.

Couch, R., and E. Nelson. 1985. Myriophyllum spicatum in North America. Pages 8-18 in Proceedings of the First International Symposium on Eurasian Watermilfoil (Myriophyllum spicatum) and Related Haloragaceae Species. Edited by L.W.J. Anderson. Aquatic Plant Management Society, Vancouver, British Columbia, Canada..

Creed, R.P. 1998. A biogeographic perspective on Eurasian watermilfoil declines: additional evidence for the role of herbivorous weevils in promoting declines? Journal of Aquatic Plant Management 36: 16-22.

Cronk, J.K., and M.S. Fennessy. 2001. Wetland Plants: Biology and Ecology. CRC Press, Boca Raton, Florida, USA. https://doi.org/10.1201/9781420032925

Duffy, K.C., and D.M. Baltz. 1998. Comparison of fish assemblages associated with native and exotic submerged macrophytes in the Lake Pontchartrain estuary, USA. Journal of Experimental Marine Biology and Ecology 223: 199-221. https://doi.org/10.1016/S0022-0981(97)00166-4

Dunbar, M.J., K. Alfredsen, and A. Harby. 2011. Hydraulichabitat modelling for setting environmental river flow needs for salmonids. Fisheries Management and Ecology 19: 500517. https://doi.org/10.1111/j.1365-2400.2011.00825.x

Eiswerth, M.E., S.G. Donaldson, and W.S. Johnson. 2000. Potential environmental impacts and economic damages of Eurasian Watermilfoil (Myriophyllum spicatum) in western Nevada and northeastern California. Weed Technology 14: 511-518. https://doi.org/10.1614/0890-037X(2000)014[05 11:PEIAED]2.0.CO;2

Fazekas, A.J., M.L Kuzmina, S.G. Newmaster, and P.M. Hollingsworth. 2012. DNA barcoding methods for land plants. Methods in Molecular Biology 858: 223-252. https:// doi.org/10.1007/978-1-61779-591-6_111

Grace, J.B., and R.G. Wetzel. 1978. The production biology of Eurasian watermilfoil (Myriophyllum spicatum L.): a review. Journal of Aquatic Plant Management 16: 1-11.

Hill, R., and S. Williams. 2007. Maine Field Guide to Invasive Aquatic Plants and Their Common Native Look Alikes. J.S. McCarthy Printers, Augusta, Maine, USA.

Hinds, H.R. 2000. Flora of New Brunswick. Second Edition. University of New Brunswick, Department of Biology, Fredericton, New Brunswick, Canada.

Johnson, L.E., A. Ricciardi, and J.T. Carlton. 2001. Overland dispersal of aquatic invasive species: a risk assessment of transient recreational boating. Ecological Applications 
11: 1789-1799. https://doi.org/10.1890/1051-0761(2001) 011[1789:ODOAIS]2.0.CO;2

Kimbel, J.C. 1982. Factors influencing potential intralake colonization by Myriophyllum spicatum L. Aquatic Botany 14: 295-307. https://doi.org/10.1016/0304-3770(82)9010 4-8

Kovalenko, K.E., and E.D. Dibble. 2014. Invasive macrophyte effects on littoral trophic structure and carbon sources. Hydrobiologia 721: 23-34. https://doi.org/10.1007/s10750013-1633-3

Laikre, L., M.K. Schwartz, R.S. Waples, N. Ryman, and The GeM Working Group. 2010. Compromising genetic diversity in the wild: unmonitored large-scale release of plants and animals. Trends in Ecology \& Evolution 25: 520 529. https://doi.org/10.1016/j.tree.2010.06.013

Madsen, J.D., J.W. Sutherland, J.A Bloomfield, L.W. Eichler, and C.W. Boylen. 1991. The decline of native vegetation under dense Eurasian watermilfoil canopies. Journal of Aquatic Plant Management 29: 94-99.

Milhous, R.T. 1999. History, theory, use, and limitations of the physical habitat simulation system. Proceedings of the Third International Symposium on Ecohydraulics. Utah State University Extension, Logan, Utah, USA.

Milhous, R.T., D.L. Wegner, and T. Waddle. 1981. User's guide to the Physical Habitat Simulation System (PHABSIM). United States Fish and Wildlife Service, Fort Collins, Colorado, USA.

Moody, M.L., and D.H. Les. 2002. Evidence of hybridity in invasive watermilfoil (Myriophyllum) populations. Proceedings of the National Academy of Science 23: 1486714871. https://doi.org/10.1073/pnas.172391499

Moody, M.L., and D.H. Les. 2007. Geographic distribution and genotypic composition of invasive hybrid watermilfoil (Myriophyllum spicatum $\times$ M. sibiricum) populations in North America. Biological Invasions 9: 559-570. https:// doi.org/10.1007/s10530-006-9058-9

NCBI Resource Coordinators. 2016. Database resources of the National Center for Biotechnology Information. Nucleic Acids Research 44: 7-19 https://doi.org/10.1093/nar/gkv 1290

Newroth, P.R. 1985. A review of Eurasian Watermilfoil impacts and management in British Columbia. Pages 139-153 in Proceedings of the First International Symposium on Eurasian Watermilfoil (Myriophyllum spicatum) and Related Haloragaceae Species. Edited by L.W.J. Anderson. Aquatic Plant Management Society, Vancouver, British Columbia, Canada.

Nichols, S.A., and B.H. Shaw. 1986. Ecological life histories of the three aquatic nuisance plants, Myriophyllum spicatum, Potamogeton crispus and Elodea canadensis. Hydrobiologia 131:3-21. https://doi.org/10.1007/BF00008319

Papoulias, M.M., M. Chaplin, and G. Bishop. 2006. Flora of the Grand Lake Meadows. Results of a vascular plant inventory and community ecology study of the Grand Lake Meadows Project Boundary Area. New Brunswick Federation of Naturalists, Fredericton, New Brunswick, Canada.

Pimentel, D., R. Zuniga, and D. Morrison. Update on the environmental and economic costs associated with alieninvasive species in the United States. Ecological Economics 52:273-288. https://doi.org/10.1016/j.ecolecon.2004.10.002

Ratnasingham, S., and P.D.N. Hebert. 2007. The Barcoding of life data system (www.barcodinglife.org). Molecular
Ecology Notes 7:355-364. https://doi.org/10.1111/j.14718286.2007.01678.x

Reed, C.F. 1977. History and distribution of Eurasian Watermilfoil in United States and Canada. Phytologia 36: 416436.

Rothlisberger, J.D., W.L. Chadderton, J. McNulty, and D.M. Lodge. 2010. Aquatic invasive species transport via trailered boats: what is being moved, who is moving it, and what can be done. Fisheries 35: 121-132. https://doi.org/ 10.1577/1548-8446-35.3.121

Sennikov, A.N. 2016. Proposal to conserve the name Myriophyllum spicatum (Haloragaceae) with a conserved type. Taxon 65: 1178-1179. https://doi.org/10.12705/655.26

Smith, C.S., and J.W. Barko. 1990. Ecology of Eurasian Watermilfoil. Journal of Aquatic Plant Management 28: 55-64.

Strand, J.A., and S.E.B. Weisner. 2001. Morphological plastic responses to water depth and wave exposure in aquatic plant (Myriophyllum spicatum). Journal of Ecology 89: 166-175. https://doi.org/10.1046/j.1365-2745.2001.00530.x

Sturtevant, A.P., N. Hatley, G.D. Pullman, R. Sheick, D. Shorez, A. Bordine, R. Mausolf, A. Lewis, R. Sutter, and A. Mortimer. 2009. Molecular characterization of Eurasian Watermilfoil, Northern Milfoil, and the invasive interspecific hybrid in Michigan lakes. Journal of Aquatic Plant Management 47: 128-135.

Titus, J., R.A. Goldstein, M.S. Adams, J.B. Mankin, R.V. O'Neill, P.R. Weiler, Jr., H.H. Shugart, and R.S. Booth. 1975. A production model for Myriophyllum spicatum L. Ecology 56: 1129-1138. https://doi.org/10.2307/1936152

Thomaz, S.M., and E.R. da Cunha. 2010. The role of macrophytes in habitat structuring in aquatic ecosystems: methods of measurement, causes and consequences on animal assemblages' composition and biodiversity. Acta Limnologica Brasiliensia 22: 218-236. https://doi.org/10.4322/actalb.02 202011

Villamagna, A.M., and B.R. Murphy. 2010. Ecological and socio-economic impacts of invasive water hyacinth (Eichhornia crassipes): a review. Freshwater Biology 55: $282-$ 298. https://doi.org/10.1111/j.1365-2427.2009.02294.x

Wagner, K.J., D.F. Mitchel, J.J. Berg, and W.C. Gendron. 2008. Milfoil Ecology and Implications for Drinking Water Supplies. AWWA Research Foundation, Denver, Colorado, USA.

Wang, T.C., J.C. Weissman, G. Ramesh, R. Varadarajan, and J.R. Benemann. 1996. Parameters for removal of toxic heavy metals by water milfoil (Myriophyllum spicatum). Bulletin of Environmental Contamination and Toxicology 57: 779-786. https://doi.org/10.1007/s001289900257

Westbrooks, W.G. 1998. Invasive Plants: Changing the Landscape of America. Federal Interagency Committee for the Management of Noxious and Exotic Weeds, Washington, DC, USA.

Willby, N. 2007. Managing aquatic plants: problems and prospects. Aquatic Conservation: Marine and Freshwater Ecosystems 17: 659-665. https://doi.org/10.1002/aqc.913

Zedler, J.B., and S. Kercher. 2004. Causes and consequences of invasive plants in wetlands: opportunities, opportunists and outcomes. Critical Reviews in Plant Sciences 23: 431452. https://doi.org/10.1080/07352680490514673

Received 30 March 2017

Accepted 27 March 2018 